Heino Nyyssönen, Adjunct Professor, Lecturer

Political Science, University of Turku

heino.nyyssonen@utu.fi; nyyssonen.heino@gmail.com

$+358445160563$

Jussi Metsälä, Ph.D. Candidate

International Relations, School of Management, University of Tampere

metsala.jussi.a@student.uta.fi

$+358408349548$

\title{
Building on Legacy and Tradition: Commemorations of 1956 in Hungary
}

\begin{abstract}
This article examines the political use of history as construction of traditions, concentrating on the identity building surrounding the National Day commemorating the Revolution of 1956 (23rd October) in Hungary. The study analyses public discourse, represented by Hungarian newspapers, related to the commemorations. Our discussion draws on three ideal types: 1996 (Hungary's new democracy), 2006 (renewal of historical conflict) and 2016 (legitimisation of the administration). We claim that the question is not merely of an invention of tradition but a separation between legacy and tradition. Whereas legacy is given, although not always remembered, traditions can be selected and commemorated.
\end{abstract}

Keywords: Hungary; History; Tradition; Commemoration; 1956, Democracy, Nationalism 


\section{Building on Legacy and Tradition: Commemorations of 1956 in Hungary}

\section{Introduction}

Yes, we Hungarians have two revolutionary traditions: one leads from 1848, through 1956 and the fall of communism, all the way to the Fundamental Law and the current constitutional order; the bloodline of the other tradition leads from Jacobin European ancestors, through 1919, to communism after World War II and the Soviet era in Hungary. Life in Hungary today is a creation of the spiritual heirs and offspring of the ' 48 and '56 revolutions. Today, as then, the heartbeat of this revolutionary tradition moves and guides the nation's political, economic and spiritual life: equality before the law, responsible government, a national bank, the sharing of burdens, respect for human dignity and the unification of the nation. (Orbán 2016.) ${ }^{1}$

This is an excerpt from a speech Hungary's Prime Minister Viktor Orbán delivered on National Holiday, commemorating 1848, on March $15^{\text {th, } 2016 .}{ }^{2}$ Thus, the purpose of this article is to study the role of history in politics, mostly in identity building. There our claim is that traditions are not merely invented in the sense of Hobsbawm and Ranger (1983), or distinguished between "invented" and "genuine" traditions, but we should separate and make a distinction between legacy and tradition: whereas legacy is given, although not always remembered, a tradition is more actively selected and commemorated ${ }^{3}$. Consequently, this article examines the construction of national traditions in Hungary, or more precisely, we study the phenomena surrounding the National Day commemorating the Revolution of 1956 (23 ${ }^{\text {rd }}$ October). However, instead of merely studying different interpretations of 1956, we concentrate on analysing the commemoration of it, particularly after 1989, when 1956 was raised as an official basis for the new republic. We claim that in this case commemorations with the use of history has been extremely controversial: instead of further helping to democratise the country it has fermented confrontation between opposite interpretations, and naturally also between opposing interpreters, of the past.

The concept use of history entails many differing forms of utilisation of the past, ranging from innocent references to ancient incidences to conscious perversions of the historical record. What is now seen - from some perspective - as a normal and acceptable form of applying historical analogies might not be seen similarly always. And recognising this ambiguous nature leads to the realisation that assignment of different labels (e.g. use, misuse and abuse) easily becomes a political act per se. (Cf. Wirth 2000, 29-33, 38. $)^{4}$ In the light of this all it is necessary to state that in this 
article we utilise merely the main concept use to describe all the possible forms of use of history and endeavour to withhold any moralising - and ultimately political - labels. The one important fact to remember is that the use of history is always selective, certain parts of the past are recalled and others overlooked. ${ }^{5}$ Our main aim is to study the different usage of the past in connection to political identity building since 1989 as characterised by various Hungarian newspapers ${ }^{6}$.

The date $23^{\text {rd }}$ October is the starting point of perhaps the most significant conflict in the Cold-War Europe, the Hungarian Revolution of 1956. In this context, the use of history was immanent already in 1989 (de facto earlier, too): in 1989 it was the date on which Hungary, as the first country in the former Eastern Bloc, changed its political system peacefully from a People's Republic to a Republic. Before 2012 the anniversary was celebrated formally in commemoration of both the 1956 Revolution and the 1989 declaration of the Republic, until this latter meaning was omitted from the new "Fidesz Constitution". This date also has several and contested political layers, for instance in 2006 the anniversary was branded by several demonstrations that were violently dispersed by the police. (Nyyssönen $2008,178.)^{7}$

Hungary's long and rich national history makes it an exceptionally good case to study the use of history for tradition-building. Hungary is by no means unique in this regard in the world, but the country's several changes in political system during the past century have tightly tied history and historiography to political power and conflict. In addition to religious authority, also historical authority can be - and has been - used to "vindicate us and judge us, and damn those who oppose us", as Margaret MacMillan $(2010,20)$ positions it. This is an important issue for this article, as it is also essential to consider questions of political change: politics plays out not only in the near and extended future, but also in the near and more distant past.

The controversies connected to 1956 have been historical in nature, for example concerning the aims of the revolution. But the interpretations are also connected to the present, relating to who is entitled to memory and historical tradition and who or what groups get to foster the national heritage. It is a question not simply of safeguarding the basic requirements of historical research, but also of much more complicated politics of history. Here the present, and everchanging, situations define the meaningful parts of the past.

Our discussion will also draw on three ideal types, namely the perspectives of 1996, 2006 and 2016. We use these as points of references, as "windows" to analyse the earlier years and public discourses taken place. In this context 1996 represents Hungary's new democracy and the thought of national reconciliation, whereas the usage of 2006 is more critical and points to the renewal of historical conflict. Finally, in 2016 the past was both used to legitimise and to challenge the present 
Fidesz reign. The use of these concepts is based on Reinhart Koselleck's idea of experience and expectation, both of which define the present simultaneously (see Koselleck 1989).

This article does not endeavour to contest any established claims of historical research. What we are interested in are the practises of looking for answers or affirmation in the past for present situations; something that Jeremy Black calls "public history" ${ }^{8}$ As can be inferred from the aforementioned examples, the problems associated with the use of history do not result from any lack of research on the historical event itself; autumn 1956 is one of the most extensively studied periods of Hungarian history. Even at the present, there are several institutes focussed on contemporary Hungarian history, but the main problem in this regard is the increasingly close relationship between research, funding, and politics. For example, right after the 2010 elections the ruling Fidesz party cut the funding of the current 1956 research institute. (Népszabadság 11 November 2010 \& 30 December 2010.) This decision could be justified by claims that the quite narrowly focussed institute had already served its purpose. However, in regard to funding policies the question is not so simple, since other research institutes closely associated with the government are still in operation. To summarise; the questionable part is not the knowledge or lack thereof, but the usage of this knowledge in politics.

\section{The Past Between Legacy and Tradition}

Hayden White has outlined the metaphorical relation of the present and past in his Figural Realism: Studies in the Mimesis Effect (1999). Historical events do not just happen; they are also made meaningful - they are knowingly or unknowingly valued. White's discussion of Erich Auerbach's work presents an interesting idea of how later events can act as the fulfilment of earlier events. The relation of the Old Testament and Christianity is one such example, but the relationship is metaphorical rather than causal. Likewise, Marx did not suggest that the historical grounds for the events in France of February 1848 could be found in the 1789 Revolution; that is, 1848 was not a direct historical consequence of 1789. The genealogy between the two events can be found in the degree of identification by the later agents with the idea of concluding the earlier revolution with another one. (White 1999.) There seems to be clear risks in this, one of the most typical of which is the new Soviet society sketched by Lenin based on The Paris Commune in The State and Revolution. ${ }^{9}$ From an ideological perspective, the past can be seen as prophesy. In this sense history is teleological, having a certain and final culmination point, to which everything inevitably leads. Past injustices strengthen the present devotion, even if the past itself must be made suitable for the prevalent understanding. (MacMillan 2010, 63-65, 67.) 
We argue that in these cases a choice between legacy and tradition has already been made: historical legacy is always broader than the parts of it that are moulded into tradition. Legacy is something imposed by the past, tradition something one aspires to. Applying the Koselleckian distinction of subjective and objective time we argue that legacy represents the (past) objective time, whilst tradition is the subjective time i.e. those parts a group wishes to remember. Who "invents" and what kind of tradition is invented are undoubtedly political questions, particularly in transitional societies.

Similarly, connected to the separation of legacy and tradition, we also consider history and memory to be two similarly separate things. For the historian, the narratives of memories can serve as pieces of evidence, as traces amongst other sources. Additionally, memory helps to reconstruct historical experiences. A third link between history and memory is the study of actual forms of memory and remembering, for example through memoirs and autobiographies. Only in fourth place in Allan Megill's classification is a type of remembrance - different from the other historical forms of memory - that is often religious or ideological in nature, and that goes well beyond the aims of historical research. Here memory becomes commemoration through veneration. (Megill 2007, 29 30; Wirth 2000, 33-34; cf. Nora 1989, 8-9, 13-18.) ${ }^{10}$

In fact, Pierre Nora has described most compellingly the layered nature of history and its uses, or how historical events - or more accurately their later interpretations - are used and reused again and again to form and transmit traditions (Nora 1996, xxiv; see also Nora 1989, 9-10). Our perception of the past is constructed, demolished and reconstructed continuously, and not only by academic historians. In this sense, also the past futures, i.e. how contemporaries saw their future and what they aspired to, is something that should be considered. (Martin 2004, 107, 123; cf. Wirth 2000, 26-28.)

But commemoration of the past is not just annually recurring celebration of some event that is seen as worthy of preservation. Certain years are more important than others; for instance, Jeremy Black has noted an interesting phenomenon connected to various anniversaries, which he calls "the cult of the centenary, bicentenary and so on". This could also be described as a tendency to emphasise suitable temporal patterns in commemoration, such as round numbers, e.g. 10, 50, 100 etc. (MacMillan 2010, 4-5; Black 2005, 17-18.)

If a certain historical event or tradition is enshrined in a Constitution, for example, is it then a part of history or of memory? According to Richard Ned Lebow, individual memory means simply what people remember or think they remember. Collective memory refers to the situations where a large group of people share, or imagine sharing, certain perceptions of the past. Furthermore, institutional memory is found in the direct practices by which political elites and their 
rivals assign meanings to the past and try to imbed them in the fabric of society. For Lebow, this last aspect of memory is politically the most significant - but not the only one - because it makes it possible to deal with the use of memory in political contexts. (Lebow 2006, 11-14; cf. Bell 2006, 2.) In this sense, collective memory is not about the past as much it is about the present, with all the possible controversies and disagreements of political life in any given time and place (Lebow 2008, 25-27; Black 2005, 21; MacMillan 2010, 48-49).

The connection of use of history and nationalism is certainly well established, collectively imagined past holds together the imagined community in the present (see Anderson 1991). However, a unified commemoration can be hampered in the case of a complicated and multifaceted past. Therefore, simplification of the past is almost necessary for any political use of the past (MacMillan 2010, 58-59, 81-82, 128-136). However, as Jeremy Black (2005, 7-8) notes, the public histories of nation states are not composed of just a single imagination, but there are a multitude of competing opinions about the past; public history, as all history, is an expression of power of certain interpretations over others.

There is also the possibility that the tendency to resort to national narratives - depicting the achievements and excellence of one's own nation - proliferates (Lebow 2008, 31-32). In modern Hungary, as far as we see, this possibility is becoming heavily emphasised. Hungarian historian Ignác Romsics recently remarked that he has not experienced such a harsh conflict over the interpretation of history anywhere else than in Hungary: not in the United States, France, Finland, South-Korea or Romania (Népszabadság 29 August 2015).

Our aim is to discover the nature of the tradition-building, or merely the selective use of legacy ${ }^{11}$. The different uses of the past can also be examined on several levels: the first level is the historian, who through his/her research questions becomes a part of the research subject and topic. The second level is the research subject itself and the use and understanding of history it presents. The third - and most important to us - level is the public, openly political level, where the influence of expertise on the common perception of history is no longer self-evident, which is also true of the neutral attitude of other actors towards the matter. This makes it possible to "find" suitable solutions from the past for current political situations and to cement these solutions into the fabric of society, ready to be passed along the chain of generations.

\section{The perspective on the $40^{\text {th }}$ Anniversary, from 1987 onwards}

We claim that the special characteristic of Hungary's transition was to connect the change to history. Although history has been present in politics all the way from the Baltic to Serbian anniversary of Kosovo Polje 1389, particularly the Hungarians have been active in this sense. These 
undertakings included a new interpretation of the events of 1956 by the Hungarian Socialist Workers' Party in early 1989, and the re-burial of Prime Minister Imre Nagy in June of the same year. After the round table negotiations, the "Crossing of the Rubicon" was held on October $23^{\text {rd }}$, the anniversary of the 1956. So, on that date in 1989, Hungary was declared a Republic; first of its kind in the former socialist countries. (see Tőkés 1996.)

The prospect to use October $23^{\text {rd }}$ as the birth date of the new republic had arisen several times during 1989, and even the first law passed by the freely elected Parliament invoked this date. Before 1989 the whole "1956" had been a taboo topic: for the Hungarian Socialist Workers' Party the interpretation, counter-revolution, represented institutional memory. During the anniversaries, the media was either silent, or tried to draw attention to the attack on a party building on Republic Square in Budapest that took place on October $30^{\text {th, }}$ 1956. The subsequent lynchings were from the perspective of the party indisputable evidence of the spreading counter-revolutionary terror. (Nyyssönen 1999, 87-110.) $)^{12}$ For the ruling party October $23^{\text {rd }}$ had its inconvenient legacy, whilst for the emerging opposition it was a political tradition to be proud of.

Thus, when the new freely elected Parliament assembled for the first time on May $2^{\text {nd, }}$ 1990, it passed a law on the historical meaning - as interpreted by the new Parliament - of the "1956 Revolution and its struggle for freedom". The first clause of the law codified the meaning of a historical event into legislation, and the second clause declared October $23^{\text {rd }}$ a National Day. The new Speaker of the National Assembly of Hungary, historian György Szabad, declared the 1956 Revolution as the most important bond with history and the historical foundation of the Third Republic of Hungary. (1990 Országgyülési Értesitö, 22; Litván 1996, x; Nyyssönen 2010, 153-156; Magyar Nemzet 3 May 1990.) However, as codifying history with laws is clearly a very public case of political use of history, then the first seeds of discord were sown already in the first session of the Parliament (cf. Garton Ash 2015). At that time, however, the main controversy dealt with the topic, why Imre Nagy's, the revolutionary Prime Minister in 1956, name was ousted from the draft in the last minutes. In 1996, thus, based on their understanding of the past, the socialist-liberal government institutionalised his memory by drafting a separate Imre Nagy memorial law on the centenary of his birth. $^{13}$

Although at the opening of Parliament 1956 was considered the bedrock of the new Republic, soon this tradition had to compete with other legacies and traditions. Less than two months later, the Parliament restored the use of the coat of arms used in the period between the World Wars. During the most radical times, like in 1848, 1918, 1946 or 1956, the coat of arms in use - the so-called Kossuth version - lacked the crown on top. Particularly the left-leaning advocates were worried, since 1956 seemed to be yielding in favour of older traditions, such as the 
inter-war period of Regent Miklós Horthy's authoritarianism, and even to those of the far right. Thus, various demands related to the Kossuth coat of arms have surfaced every now and then. For example, in 2012, the leader of the MSZP Attila Mesterházy plainly and very publicly used history as a political instrument by asking Hungarians to bear the Kossuth coat of arms until the fourth Republic was formed. (Népszabadság 24 October 2013 \& 24 October 2012; Magyar Nemzet 16 March 2015.)

The proper debate about anniversaries, i.e. institutional memory, took place in March 1991, when there were three propositions for national holidays: March $15^{\text {th }}$, in honour of the revolution of 1848; August $20^{\text {th }}$, in honour of Saint Stephen, the first king and founder of the state of Hungary; and October $23^{\text {rd }}$. After parliamentary deliberation, it was decided to make August $20^{\text {th }}$ an official state holiday, a date that historically anchored Hungary also to the Roman Catholic Church. This decision also meant that the March and October dates would become National Days. At this point legislators still attached two meanings to the October date: both the 1956 Revolution and the 1989 declaration of the Republic. (Nyyssönen 2008, 172-180.) ${ }^{14}$

Thus, the Parliament itself was a significant lieu de mémoire also in regard to the year 1956. There was a historical continuity, as several central veterans of 1956 were elected to the Parliament, including new Prime Minister József Antall, President Árpád Göncz, and Gyula Horn who later served as Prime Minister in 1994-1998. Concerning our distinction here, all three levels mattered: a thorough research work of the topic had begun, several historians had become political actors in the Parliament, and the case was present in public history, too. ${ }^{15}$

However, also historical justice and lustration can be labelled to legacies. The legislation concerning the screenings was originally passed in March 1994, so it directly affected only subsequent parliaments. Legislators found the most incriminating factors to be association with counter-espionage, membership in the fascist Arrow Cross party, and participation in repression of the 1956 Revolution. In 1996 the majority of socialist and liberals narrowed the number of people being screened, but Fidesz later extended it to include the media, judges, and lawyers.

Thus, legacies and traditions divided political actors, but by 1996, forty years after the events, the country was free of Soviet occupation, and a republic had been declared seven years earlier. A certain double transition was a fact; the nationalistic right won the first free elections in 1990. Four years later, the Hungarian Socialist Party (MSZP) won the elections, with one-third of the first-round votes. MSZP aimed to root itself in the Western European social democratic tradition, but its opponents saw it as burdened with the legacy of both the Hungarian Socialist Workers' Party (MSZMP) and the neoliberalism of the 1990s. This legacy culminated in the Prime Minister Gyula Horn (1994-1998): for his hard-line opponents he was always the man, who had 
supported the suppression of the uprising in 1956, despite belonging to the communist reformers in the 1980s.

\section{The perspective on the $50^{\text {th }}$ Anniversary, from 1997 onwards}

Seen from the perspective of 2006, many political aims had already been brought about. In 1999 Hungary had joined the North Atlantic Treaty Organisation, together with Poland and the Czech Republic, and joined the European Union along with eight other states in 2004. The pre-1989 level of economic prosperity was reached in 1997; after all, Hungary had been able to gather most of the Western investments made in the former Eastern Bloc. At the beginning of the 2000s, Hungary was quickly becoming a stable European democracy and a model member of the EU.

Most of the public commemorations, which had been institutionalised in the 1990s, repeated annually. In Budapest they took place mainly at original sites of the events that are also currently used to commemorate the events of 1956, including the technical university, the Parliament, sites of historical battles, and cemeteries. The statue of the Polish General Jozsef Bem, who aided the Hungarians in 1848, was already a location of memory in 1956. During the first decades of the Third Republic (1989-2011), the state's political elite had the demonstrative custom of collectively laying a wreath at the statue, but this practice was gradually abandoned. (Cf. Népszabadság 24 October 2008 \& 24 October 2009.) What is striking in these traditions in general, are the notions of democratic efforts of the parties and the people in 1956. However, as these ceremonies usually ended on November $4^{\text {th }}$ i.e. on the day of the second Soviet invasion, the Workers' councils, their resistance and the socialist legacy in general remained secondary.

In politics of commemoration the $50^{\text {th }}$ anniversary is somehow one of the most important: the case is already quite well studied but many eyewitnesses are still alive. In 2005 the head of the 1956 memorial committee, academic Domokos Kosary invited the leaders of political parties to a meeting: 1956 was a national matter, not something to be mixed with party politics. The government anticipated that over fifty heads of state would attend the 2006 commemorations. In the

spirit of the cult of round years, the government also supported over 500 films, conferences, exhibitions, statues and other commemorative events. ${ }^{16}$ (Nyyssönen 2010, 169-170; Csipke 2011a, 99-128.)

However, the fiftieth anniversary was held in circumstances for which few had been prepared: for the first time in the history of the new democracy, the incumbent government won reelection. This was achieved with a certain amount of misleading of the public, since the country's economic situation was not nearly as good as the socialist-liberal government implied. A secret 
speech by the Prime Minister Ferenc Gyurcsány in Balatonőszöd, in which he basically revealed in strong language that the government had lied to win the elections, was leaked to the public.

Although different interpretations of the past can belong to democracy (cf. Gyáni 2006), here the past and the present were mixed and "1956" offered the window to understand the present: The speech offered an excuse for riots and emergence of popular analogies and 1956 symbols to "repeat" history, and to label the Socialist Party to the heirs of those, who suppressed the revolution. Outside the Parliament, which was also a location of memory for events in 1956, demonstrations mostly comprised of several right-wing nationalist radical groups - continued well into the next year. The aim of these "Kossuth square demonstrators" was to bring about the replacement of Prime Minister Gyurcsány, who nonetheless retained his position in a parliamentary vote of confidence. (Nyyssönen 2010; cf. Csipke 2011b.) These commemorative events and demonstrations also have a link to the far-right Jobbik party. Jobbik has called itself the generation of 2006, and wants to supplant the generation of 1989, of which Viktor Orbán is a member.

Thus, on the National Day of $23^{\text {rd }}$ October, the international media reported on the intensified riots. The social democratic newspaper Népszava called the date "a disgraced celebration", and the conservative Magyar Nemzet wrote of police-perpetrated acts of terror on the anniversary. The newspaper pictures showed demonstrators with covered faces, and according to one caption "the participants in the riot climbed on top of armoured vehicles like there was a revolution [italics added] going on". (Magyar Nemzet \& Népszava \& Népszabadság 24 October 2006.) One of the authors of this article was in the city around noon that day watching the passing 1956 vehicles. Instead of slogans about 1956, the participants demanded the resignation of the Prime Minister Gyurcsány - use of history for some, abuse for others, but politics for everyone.

Police brutality, rubber bullets, and the role of Fidesz, as well as the spontaneity of the demonstrations, have been objects of heated discussion ever since ${ }^{17}$. Fidesz had formally declined to take part in the commemorative festivities in the Parliament, where the Prime Minister, representing the socialists, would give a speech. This special session was attended by dozens of heads-of-states and other prestigious delegates to endorse a special Declaration of Freedom. (Nyyssönen 2010, 169-170; Debreczeni 2012; Magyar Nemzet 24 October 2006 \& 22 October 2008. $)^{18}$ Already the 2002 parliamentary festivities had been tenuous, because Fidesz, after losing the elections, declined to take part. However, in the autumn of 2006 the protests developed into social movements, by which some people were, in rhetoric at least, using history and finding parallels from the events of 50 years before.

The current Prime Minister Viktor Orbán has been one of the first to challenge the prevalent political consensus over 1956, as early as the mid-1990s. During his first term in office as 
prime minister, Orbán stated that the Hungarian unanimity of 1956 was merely provisional. For instance, in a 2000 speech he claimed that the contemporary aim in 1956 was a change of regime, not a reformation of socialism. (Magyar Nemzet 24 October 2000.) Historically the revolutionary attempt was de facto interrupted, and it is mostly an ideological matter of faith to speculate on all the what-if possibilities. Until November $4^{\text {th }} 1956$ the country had already seen the emergence of several different sections of society, of which the four most important were reformers of socialism, national democratic peasants, mostly catholic conservatives, and the anti-communist far right. (Litván, 1996, 125-126.). Thus, after 1989 several political groups could find their own historical identification; and the debate is about who started the revolution, who was leading it and who owns the tradition of it.

\section{The perspective on the $60^{\text {th }}$ Anniversary, from 2007 onwards}

Counted in years, in 2018 the Hungarian flawed democracy is still younger than the Communist János Kádar regime. This is not aiming to undermine the democratic approach but rather a reminder of the complexity of the legacies and the often-legitimising nature of "long history". In 2007 President László Sólyom made the difference between legacy and tradition immanently visible: 1956 Revolution is the historical foundation of the Republic, without any continuation with the legacy of János Kádár, i.e. between the years 1956 and 1989. (Népszabadság 24 October 2007.) This ideal type is undeniably a question of political will of tradition building, which raises but also denies a part of existing history.

From the perspective of 2016 the political balance has shifted, and Hungarian standards of democratisation have deteriorated in international rankings (see Nations in Transition 2016; Democracy Index 2016). In the elections of 2010, after two socialist-liberal terms, Fidesz-KDNP won a two-thirds parliamentary majority, with 53 percent of the votes. One of the first actions of the Fidesz dominated Parliament was a statement that defined the 2010 victory as a "revolution in the voting booths". This proclamation is a clear example of the public and political use of history: it branded - consistently with the conservative interpretation of the past - the two previous decades as crises, a kind of legacy, to which a countering "system of national co-operation" was born in the election. ${ }^{19}$

In his speech on the October anniversary in 2010, Orbán envisioned the future actions of the government. According to Orbán, the history of 1956 had been unfinished (befejezetelen) history all the way up to the April 2010 elections. Now the revolution of the two-thirds had redeemed "us" - the heirs of 1956 - of the feeling that the struggle should be fought again. The struggle, in Orbán's words, had ended in April 2010 in a victory for the " $56 \mathrm{~s}$ ", regime changers, 
free Hungarians. (Magyar Hírlap 25 October 2010; Népszabadság 25 October 2010.) This is a clear attempt at political legitimation by using history, perhaps even a disgrace to professional historians: national unity is culminating in the present and in the election winner, who has also been a prominent actor in politics during the preceding twenty years. Elements of the past and present were observable in the October anniversary of 2013, too, just six months before the elections. The progovernment newspaper Magyar Hírlap (24 October 2013) carried the headline "Viktor Orbán: Now we can finish what we started in 1956".

After the hostilities of 2006 the socialist-led governmental commemorations were rather subdued. The advertisements of the official events in 2007 and 2008 used history in a way that 1956 was shared history that should be told to children and grandchildren in order to preserve the common memory. It is important to note that whereas Orbán connected the electoral victory of 2010 to the year 1956, the socialists sought legitimisation in the Republic of 1989: for them the dream of a free, independent and democratic Hungary had come true in 1989. The official announcement of 2009 commemorations was different from previous ones. It highlighted once again the cult of round numbers i.e. the twentieth anniversary of the Republic: the year 1989 legitimised the year 1956, and no-one could claim this memory as theirs alone. The socialists relocated their commemorations to Kaposvár, the birthplace of Imre Nagy. Since then they have not held any major commemorative events. (Népszabadság 20 October 2007; Magyar Nemzet 22 October 2008 \& 20 October 2009 \& 19 October 2009; Népszabadság 24 October 2009 \& 22 October 2009.)

The last years have consolidated the October anniversary into a day of expected party politics. According to a newspaper close to the Fidesz-led government: "The ideas of 1956 live on even today, and impel us to act". On another instance, a politician stated that the current demands are the same as they were then: freedom, well-being and security (Magyar Hírlap 22 October 2013; Népszabadság 24 October 2011 \& 24 October 2014). One of the organisers of the so-called peace procession (Békemenet), which emerged as a pro-government entity after the new Constitution, political scientist Tamás Fricz, remarked in 2012 that Hungary was in a state of cold civil war. ${ }^{20}$ The divisiveness of the situation came across very clearly in the movements of the 2013 anniversary, something the Népszabadság described as us-versus-them logic (Népszabadság 24 October 2013; cf. Népszava 22 October 2012).

In October 2013, one of the authors had the chance of observing the peace procession, which included a display of many slogans supporting Prime Minister Viktor Orbán and a number of Hungarian tricolours with a hole in the middle, similar to those used in 1956. The march itself was reminiscent of the 1956 student march, the purpose of which was then to show solidarity with the Poles, not with the current Hungarian government. An opposition-held event at the technical 
university under the title "Freedom unites 1956/2013" was noticeably less popular. One of the most significant actors in this case was the Together 2014 -movement, founded a year earlier and which had a background in the One Million for the Freedom of Press in Hungary -movement. The Together 2014 -movement was an attempt to unite the Left. This failed, as the movement never achieved a leading role.

The far-right Jobbik party, established in 2003, has also made a tradition of its own commemorative events. In 2009 Jobbik wanted to commemorate the police aggression three years earlier, and the 2006 anniversary to which they saw themselves as heirs. The party launched the slogan "Tanks went, Banks came" and insisted on having studies done of 1956 by nationalistic historians. Slogans like "Merkel is not needed", "Enough with the EU" or "I will not vote for Fidesz anymore" were visible at the anniversary event. (Magyar Nemzet 24 October 2013; Népszabadság 24 October 2009 \& 24 October 2011 \& 24 October 2012; Magyar Hírlap 24 October 2012.)

In spring 2016 the cult of the forthcoming anniversary was already visible in Budapest. From February onwards the whole year was nominated as "The Year of the Hungarian Freedom", with broader concentration on atrocities in the Carpathian Basin since 1944. In June a big feast "You have to live and die here" promised, in a commemorative frame of 1956, a huge tribute for outstanding events from the conquest era until the present. This time the leadership of commemoration was strongly in the hands of the government: the national memory committee was patronised by a veteran of 1956 - and a former Fidesz-MP - Mária Wittner and the Chairman of the Parliament László Kövér. Its Vice-Presidents are Minister of Human Capacities Zoltán Balog and historian Mária Schmidt, former Commissioner of the Orbán government. (A magyar szabadság éve: friss, lendületes és nagyszabású lesz az 1956-os Emlékév 2016; A Magyar Szabadság Éve 2016; Itt élned halnod kell - zenés történelmi utazás 2016.) However, as the following quote (Commemoration ceremony...) shows, not all agreed with the content of the commemorations:

During an official ceremony marking the 60th anniversary of the Hungarian Uprising at which Poland's president Andrzej Duda also delivered a speech, Prime Minister Viktor Orbán defended his government's refugee policy. Supporters of the left-wing opposition led by the Együt party disrupted the event with a barrage of whistling and catcalls. The Hungarian press voices disappointment that the commemoration was overshadowed by political squabbling.

After all, the $60^{\text {th }}$ anniversary was commemorated in the aftermath of the European migrant crisis. There the official Hungary represented a hard line, despite of its experiences in the late 1956, when 
ca. 200000 people left the country. In general, the country has found itself more isolated in the last ten years and has been warming its relations to an old friend Poland, important even in 1956. One of the authors participated in the commemorations in Budapest: instead of political leaders, large pictures of the armed boys and girls of Pest decorated public places. As some of them had sympathised or even supported the extreme right, they played now a role in this institutional memory. At the same time another revolutionary, the Prime Minister Imre Nagy, was becoming a part of the Hungarian legacy, something which was hardly mentioned in public commemorations.

\section{Conclusion}

To Hayden White the relationship between historical events was metaphorical, referring to the desire of the actors to identify with the event or phenomenon. Similarly evident are the educational narratives White mentioned that are used to encourage political action. The question of "fulfilments" on the one hand and the burden of history, i.e. between the tradition and the legacy of the recent history on the other, can be evident in many countries.

As our case has shown, history matters in politics, despite of academic study and historiography. Therefore, the use of history - clearly evident in Hungarian society and politics does not take place merely because of the lack of historiography or evidence. Contrary to Gyáni (2006), different interpretations do not necessarily represent democracy, but a struggle for a new canon. Political actors have constructed the present society, not merely on democracy or rule of law, but also on great historical moments - in this case on the two weeks and its aftermath in 1956. In this context history reminds us of great revolutionary moments and encourages radical action. Based on the examples presented in this article, it is apparent that the interpretation of the past in the present sets certain requirements and polarisation of contemporary actions. This way it could have a connection with the current development of democratisation in Hungary, which has regressed since 2006, when the Democracy Index started to measure it (Democracy Index 2016).

In Hungary history has been used in various ways, in some instances without larger political pretensions, but in others with clear ulterior motives. The Communist regime can be blamed for this but even the very first Parliament of the Republic began its work by institutionalising history. Even if the aim has been to supplement or fill in the gaps of history, history might have actually worked against these efforts and limited the political space. The 1956 anniversary itself is not always the reason for disorder, but it seems that history has become an alibi for many types of political action; an instrument of internal power politics.

After all, political traditions are a form of seeking legitimacy for current action, but their weakness lies in their difficulty to face the controversial legacies of the past. For example, even 
Jobbik party builds on tradition and sees itself as an heir of the autumn 2006, and through that, also the heir of October 1956. This all leads us to question the overall political significance of the 1956; was it after all more an expression of general opposition to Stalinism, resistance and nationalism than of democracy, anti-Semitism or White Terror - all of which are interpretations made in Hungary after 1956.

Oddly, none of the three Republics have an official commemorative day in the current Hungary. From the perspective of the Right, the Republic has been a sort of a waypoint to the "catastrophe" that has resulted from the actions of the Left during their terms. And from the perspective of the Left, the concepts "system of national co-operation" and "illiberal democracy" are in any case questionable developments. Still, it is a fact that also in 1989 Hungary made world history, like it had done during the autumn of 1956.

\section{Notes}

${ }^{1}$ In similar vein, already when Hungary was declared a Republic on October $23^{\text {rd, }} 1989$, President Mátyás Szürös declared that the new Hungary would follow in the footsteps of the earlier Republics and mentioned especially the years 1848, 1918 and 1946.

${ }^{2}$ Likewise, the new Hungarian Constitution of 2012 takes an exceptionally strong stand on history (cf. The Fundamental Law of Hungary, preamble). In addition to identity politics, the preamble of the Constitution lists separately certain historical events and people. For example, it says that the country's self-determination - lost on March $19^{\text {th }} 1944$ - was restored on May $2^{\text {nd, }} 1990$, when the new freely elected Parliament assembled for the first time. Furthermore, the preamble states "our current liberty was born of our 1956 Revolution". On the other hand, there are no mentions of the Hungarian Republic, which was declared on the anniversary of the uprising on October 23 ${ }^{\text {rd, }}$ 1989. (Magyarország Alatörvénye; Dani 2013; Bugarič 2014; Csipke 2011b.) The echoes of the past are also fervently present in Hungary's self-perceived identity as a sort of a "freedom fighter" in the EU in recent years (cf. Ágh 2012; Bozóki 2012).

${ }^{3}$ Here the concept of tradition can be described as those parts of the past that should be remembered, while the parts of the past that are rather not remembered - or even actively forgotten - belong to the much broader concept of legacy. Therefore, to us this distinction is quite similar to the relationship between the concepts of past and history. The past entails everything that has happened, but history is not the same thing. History consists of aspects of the past that are seen, or indeed made, relevant in the present. Interestingly, if the parts of the past which are chosen to be remembered in the present as a tradition - and also the very forms of remembering the chosen past - are understood as part of rhetoric and political thinking, their truth value might diminish but the political value increases. As Margaret MacMillan $(2010,113)$ reminds: "[h]istory is about remembering the past, but it is also about choosing to forget".

${ }^{4}$ This, however, does not mean that the certain facts of the past would be altered, only the interpretations of them: even in the future (our italics) Napoleon was conclusively defeated at Waterloo, as Margaret Macmillan reminds us on the matter (MacMillan 2010, 38-39). Generally on the different cases of use of history, see e.g. Black 2005 and MacMillan 2010.

${ }^{5}$ The political use of history to support and strengthen certain versions of the past concerning national values - and obviously national identity - runs the risk that it "flattens out the complexity of human experience and leaves no room for different interpretations of the past" (MacMillan 2010, 114). According to Jeremy Black, there exists a "gap between academic and public history", or between "history as questions and history as answers". (Black 2005, ix, 1-2.)

${ }^{6}$ Of the Hungarian newspapers included here as the research material are the conservative (since 2006) Magyar Hirlap and Magyar Nemzet, in contrast to the more liberal and leftist viewpoints of Népszava and 
Népszabadság, which has been closed down since October 2016. Naturally, our reading of the source material is systematic but not without the unavoidable subjective nature of historical/social scientific research.

${ }^{7}$ See also The New Fundamental Law of Hungary, especially article J, which defines national holidays. On remembering, discourses connected to the year 1956 and the political utilisation of it, see e.g. Gyáni 2006, 1199-1208; Csipke 2011a, 99-128; on significance, see Rainer 2006, 1189-1198.

${ }^{8}$ On the public use of the past, see Black 2005; on the relationship between historians and society, see Kalela 2012; on Hungary and 1956 see Nyyssönen 2008 \& 2010.

${ }^{9}$ In regard to Lenin's The State and Revolution, see especially chapter three in White 1999.

${ }^{10}$ Black (2005, 9-10), however, is somewhat skeptical about the division between memory and history.

${ }^{11}$ See Wirth $(2000,38-48)$ on the several ways in which history can be used or misused.

${ }^{12}$ As a further separation with the past, since 2011 this square, which had carried the name of the Republic since 1946, is known as the John Paul II square and subsequently as a metro station of the same name.

13 These "memory laws" are a kind of tradition in the Hungarian political culture, at least since the 19th Century. However, surprisingly many were enacted recently i.e. after 1989 (cf. Garton Ash 2015).

${ }^{14}$ According to a survey conducted in 2000, the August holiday was the most popular and October $23^{\text {rd }}$ least popular, with only six percent of respondents considering the anniversary of the 1956 Revolution as the nation's foremost holiday.

${ }^{15}$ One of the most heated arguments considered doing justice (igazságtétel). On this matter the government was willing to pass ex post facto legislation, for example for acts of treason committed between 1944 and 1990 but the Constitutional Court rejected these ideas. However, those hoping to see large-scale retribution against the proponents of the old regime were to be disappointed. This was partly a consequence of the Hungarian liberal amnesty legislation. (Népszabadság 24 August 2015 \& 2 April 2015.) In 2012, on the initiative of the Jobbik party, the case of Béla Biszku, the Minister of Interior after 1956, was reopened again. Legal proceedings against the now 94-year-old Biszku were still underway until he died in spring 2016.

${ }^{16}$ During the same year, two government-funded memorials were unveiled in the capital. The design for the first memorial was selected through an architectural competition. The second memorial was devised later on as an alternative to the official memorial, and was placed at the technical university to symbolise the "personal views" of contemporaries.

${ }^{17}$ During the afternoon Fidesz, the largest opposition party, had gathered at the city centre; the demonstrators driven by the police from the Parliament retreated in the same direction. In the resulting confusion, also Fidesz supporters were assaulted by the police.

${ }^{18}$ On the text (in Hungarian) of the Declaration ratified at the official ceremony of 2006, see Magyar Nemzet 26 October 2006.

${ }^{19}$ In the spring elections of 2014 Viktor Orbán renewed the two-thirds majority with the help of a new electoral law bringing a 45 percent share of the votes. Soon after he stated that the country had made a transition to a kind of "illiberal democracy". (Cf. Zakaria 1997; Legyen béke, szabadság és együttértés; Orbán 2014; Magyar Nemzet 15 May 2010; Népszabadság 5 July 2010.)

${ }^{20}$ Under the Fidesz regime the public commemoration has mostly followed a familiar pattern: on the eve of the $23^{\text {rd }}$ there is a memorial ceremony at the technical university and a torchlight procession along the banks of the Danube, ending in Pest with the lighting of a symbolic flame. In 2010 the conservative newspapers rejoiced that for the first time in years the events were taking place in a calm and child-friendly atmosphere without any police intervention. (Magyar Hírlap 22 October 2010; Népszabadság 22 October 2011; Magyar Nemzet 20 October 2012; Magyar Hírlap 20 October 2010; Magyar Hírlap 22 October 2010 \& 25 October 10; Magyar Nemzet 22 October 2012; Népszabadság 14 September 2015.)

\section{Sources}

Documents:

1990 Országgyülési Értesitö. 
A Magyar Szabadság Éve. Available at: www.magyarforradalom1956.hu, visited 12 May 2016.

A magyar szabadság éve: friss, lendületes és nagyszabású lesz az 1956-os Emlékév. Available at: www.kormany.hu, visited 12 May 2016.

Democracy Index 2016, The Economist Intelligence Unit. Available at http://www.eiu.com/topic/democracy-index, visited 1 May 2017.

Itt élned halnod kell - zenés történelmi utazás. Available et: www.jegy.hu, visited 12 May 2016.

Legyen béke, szabadság és együttértés. Available at: www.fidesz.hu, visited 20 February 2015.

Magyarország Alatörvénye. Available at: www.parlament.hu, visited 28 October 2015.

Nations in Transition 2016, Freedom House. Available at: $\underline{w w w . f r e e d o m h o u s e . o r g, ~ v i s i t e d ~} 19$ April 2016.

The Fundamental Law of Hungary. Available at: www.keh.hu, visited 22 March 2015.

The New Fundamental Law of Hungary. Available at: www.kormany.hu, visited 28 October 2015.

\section{Literature:}

Ágh, Attila (2012) “The Hungarian Rhapsodies: The Conflict of Adventurism and Professionalism in the European Union Presidency”. Journal of Common Market Studies 50(1): 68-75.

Anderson, Benedict (1991) Imagined Communities: Reflections on the Origin and Spread of Nationalism. London: Verso.

Bell, Duncan (2006) “Introduction: Memory, Trauma and World Politics”. In Duncan Bell (ed.) Memory, Trauma and World Politics: Reflections on the Relationship Between Past and Present. Basingstoke: Palgrave Macmillan, 1-29.

Black, Jeremy (2005) Using History. London: Hodder Arnold. 
Bozóki, András (2012) The Crisis of Democracy in Hungary, 2012. Available at: www.deliberatelyconsidered.com, visited 11 February 2015.

Bugarič, Bojan (2014) "Protecting Democracy and the Rule of Law in the European Union: The Hungarian Challenge”. LEQS Paper No. 79/2014 July 2014. Available at: $\underline{w w w . l s e . a c . u k}$, visited 22 February 2015.

Commemoration ceremony for the Hungarian Revolution disrupted. Available at: www.eurotopics.net, visited 30 January 2017.

Csipke, Zoltán (2011a) “The Changing Significance of the 1956 Revolution in Post-Communist Hungary". Europa-Asia Studies 63 (1): 99-128.

Csipke, Zoltán (2011b) "The end of the "Republic of Hungary" draws near". Available at: www.politico.hu, visited 30 March 2016.

Dani, Marco (2013) “The 'Partisan Constitution' and the corrosion of European constitutional culture". LEQS Paper No. 68/2013 November 2013. Available at: $\underline{\text { www.lse.ac.uk, visited }}$ 22 February 2015.

Debreczeni, József (2012) A 2006-os ösz. Budapest: De.hu.

Garton Ash, Timothy (2015) "Free Speech and the Study of History - Colin Matthew Memorial Lecture for the Public Understanding of History". Available at: http://www.gresham.ac.uk/lecture/transcript/download/free-speech-and-the-study-ofhistoryl, visited 18 May 2016.

Gyáni, Gábor (2006) "Memory and discussion on the 1956 Hungarian Revolution”. Europa-Asia Studies 58 (8): 1199-1208.

Hobsbawm, Eric \& Terrence Ranger (1983) The Invention of Tradition. Cambridge: Cambridge University Press. 
Kalela, Jorma (2012) Making History. The Historian and the Uses of the Past. Basingstoke: Palgrave McMillan.

Koselleck, Reinhart (1989) Vergangene Zukunft: Zur Semantik geschichtlicher Zeiten. Frankfurt: Suhrkamp.

Lebow, Richard, Ned (2006) “The Memory of Politics in Postwar Europe”. In Richard Ned Lebow \& Wulf Kansteiner \& Claudio Fogu (eds.) The Politics of Memory in Postwar Europe. Durham and London: Duke University Press, 1-39.

Lebow, Richard, Ned (2008) "The Future of Memory". The ANNALS of the American Academy of Political and Social Science 617 (1): 25-41.

Litván, György (ed.) (1996) The Hungarian Revolution of 1956: Reform, Revolt and Repression 1953-1963. London and New York: Longman.

MacMillan, Margaret (2010) The Uses and Abuses of History. London: Profile Books.

Martin, Ged (2004) Past Futures. The Impossible Necessity of History. Toronto: University of Toronto Press.

Megill, Allan (2007) Historical Knowledge, Historical Error: A Contemporary Guide to Practice. Chicago, London: The University of Chicago Press.

Nora, Pierre (1989) "Between Memory and History: Les Lieux de Mémoire”. Representations 26: $7-24$.

Nora, Pierre (1996) "Preface to the English Language Edition". In Pierre Nora \& Lawrence D. Kritzman (eds.) Realms of Memory - The Construction of the French Past, Vol. 1 Conflicts and Divisions. New York: Columbia University Press.

Nyyssönen, Heino (1999) The Presence of the Past in Politics. '1956' after 1956 in Hungary. Jyväskylä: SoPhi. 
Nyyssönen, Heino (2008) “Contested Traditions? The Uses of National Holidays in Hungary”. In Harald Wydra \& Alexander Woell (eds.) Myth and Democracy in Eastern Europe. BASEES/Routledge Series on Russian and East European studies 36. London: Routledge.

Nyyssönen, Heino (2010) “1956 in the Republic of Hungary since 1989”. In Christopher Adam, Tibor Egervari, Leslie Laczko \& Judy Young (eds.) The 1956 Hungarian Revolution: Hungarian \& Canadian Perspectives. Ottawa: Ottawa University Press, 151-174.

Orbán, Viktor (2014) A munkaalapú állam korszaka következik. Available at: www.mandiner.hu, visited 20 February 2015.

Orbán, Viktor (2016) Speech by Prime Minister Viktor Orbán on 15 March. Available at: www.kormany.hu, visited 20 may 2016.

Rainer, János M. (2006) “1956: the mid-twentieth century seen from the vantage point of the beginning of the next century". Europa-Asia Studies 58 (8): 1189-1198.

Tökés, Rudolf (1996) Hungary's negotiated revolution. Economic reform, social change and political succession. Cambridge Russian, Soviet and Post-Soviet Studies 101. Cambridge: University Press.

White, Hayden (1999) Figural Realism. Studies in the Mimesis Effect. Baltimore and London: Johns Hopkins University Press.

Wirth, Laurent (2000) "Facing misuses of history". In Iggers, Georg \& Laurent Wirth The misuse of history. Strasbourg: Council of Europe Publishing.

Zakaria, Fareed (1997) “The Rise of Illiberal Democracy”. Foreign Affairs 76 (6): 22-42.

Hungarian Newspapers:

Magyar Hírlap 
Magyar Nemzet

Népszabadság

Népszava 